\title{
Identification of Recharge Controls for Groundwater Aquifer System by Stable Water Isotopes
}

\author{
Mohamad Sapari Dwi Hadian", Bombom Rachmat Suganda", Mochamad Nursiyam Barkah", Satrio*, \\ Hendarmawan ${ }^{\#}$ \\ ${ }^{\#}$ Hydrogeology and Environmental Geology laboratory, Universitas Padjadjaran, Indonesia \\ E-mail: sapari@unpad.ac.id; bombom.rachmat.suganda@unpad.ac.id; m.nursiyam@unpad.ac.id; hendarmawan@unpad.ac.id \\ ${ }^{*}$ Center for Isotopes and Radiation Application, Batan, Indonesia \\ E-mail: satrio@batan.go.id
}

\begin{abstract}
A decrease in groundwater level, especially shallow groundwater, occurred in the residential areas, and Padjadjaran University of Jatinangor part of Manglayang slope, a volcanic region at West Java Indonesia. This is due to an imbalance between groundwater input and extraction. This research aims to compile data on physical characteristics of rock lithology containing groundwater, and identifying various layers of groundwater carriers. Groundwater samples were taken in the aquifer system at the study area of the Manglayang volcanic region, and analyses using the composition diagram method and chemical analysis were conducted. The old volcanic deposit was found based on geological mapping, hydrogeology, electrical sounding measure, and boring in the area at the distal and media regime. The tuff deposit with pale soil, young deposit product is dominant in the area where there are lava and lava dome that reached the peak. There are also three types of lava, which is basalt augite, basalt, and andesite. Springwater was found at the 650 - $800 \mathrm{mdpl}$ elevation. It has the facies $\mathrm{Ca}, \mathrm{Mg} \mathrm{HCO}_{3}$ (Calcium, Magnesium bicarbonate), and facies $\mathrm{Mg} \mathrm{HCO}_{3}(\mathrm{Magnesium}$ bicarbonate). The area has a local groundwater flow system above the elevation of $900 \mathrm{MSL}$ and an intermediate groundwater flow system below elevation $900 \mathrm{MSL}$. The study found water catchment area is located in two places, which are zone in the elevation 900 to $1100 \mathrm{~m}$ with local flow patterns and $1379 \mathrm{~m}$ to $1697 \mathrm{~m}$ system intermediate. From these results, a zoning map can be developed based on the distribution of rocks and the sequences of rock formation. The study can also be utilized to determine the conservation zones' location based on the forms of delivery from each layer of rock.
\end{abstract}

Keywords—-groundwater facies; isotope; hydrochemical; volcanic; Manglayang.

\section{INTRODUCTION}

Problems that occur each year is the potential of groundwater in the study area of Manglayang volcanic region in West Java Indonesia shows a decrease in groundwater level, especially shallow groundwater. This is due to an imbalance between the groundwater input and the output or groundwater extraction. Other than the inputoutput imbalance, shallow groundwater level reduction is also expected to reduced absorption areas and changes in the function of recharge areas into separate tasks. The function changes are the closure of recharge areas by housing construction, road infrastructure and other facilities needed for settlement and regional development. For this reason, it is necessary to determine recharge areas and evaluate the domains starting from the elevation and land cover character. The study in the groundwater recharge system includes groundwater hydrogeology, hydrodynamics conditions, groundwater facies and groundwater age in the study area. The specific target to be achieved through this research is the compilation of databases containing physical characteristics of rock lithology containing groundwater, as well as identifying various layers of groundwater carriers. Several previous studies have to use groundwater isotopes in defining inflow water and deliate recharge zone [1], surrounding the Bandung basin [2], [3].

From this study, a zoning map for the distribution of rocks was made and a description of the rock formation sequence. The study also describes the forms of distribution from each layer of rock, conservation zones, and recommendations for future development in the area.

\section{MATERIAL AND METHOD}

In order to determine the recharge controls, the water stable isotope method is utilized. Other methods, such as using hydrochemical and groundwater facies, have been 
used for a long time [4]-[6]. However, the results of this method have limitations where the parameters are limited. Therefore, the result does not detail. Other than that, it can be influenced by geological control, and the result cannot be validated accurately. Studies using a water stable isotope method found that the results could be verified more accurately than the other techniques, as Darling stated [7][9].

The research process starts with a literature study on groundwater assessment; the fieldwork is conducted to collect data on stable water isotopes, water chemistry, and rainfall. The rainfall data is collected every month for a year period in the Padjadjaran university campus, the Jatinangor area part of the Manglayang Volcanic area. After data collection, mapping is done to find out about the geological setting and collect a sample of rocks and groundwater. The detailed research process can be seen in figure 1 .

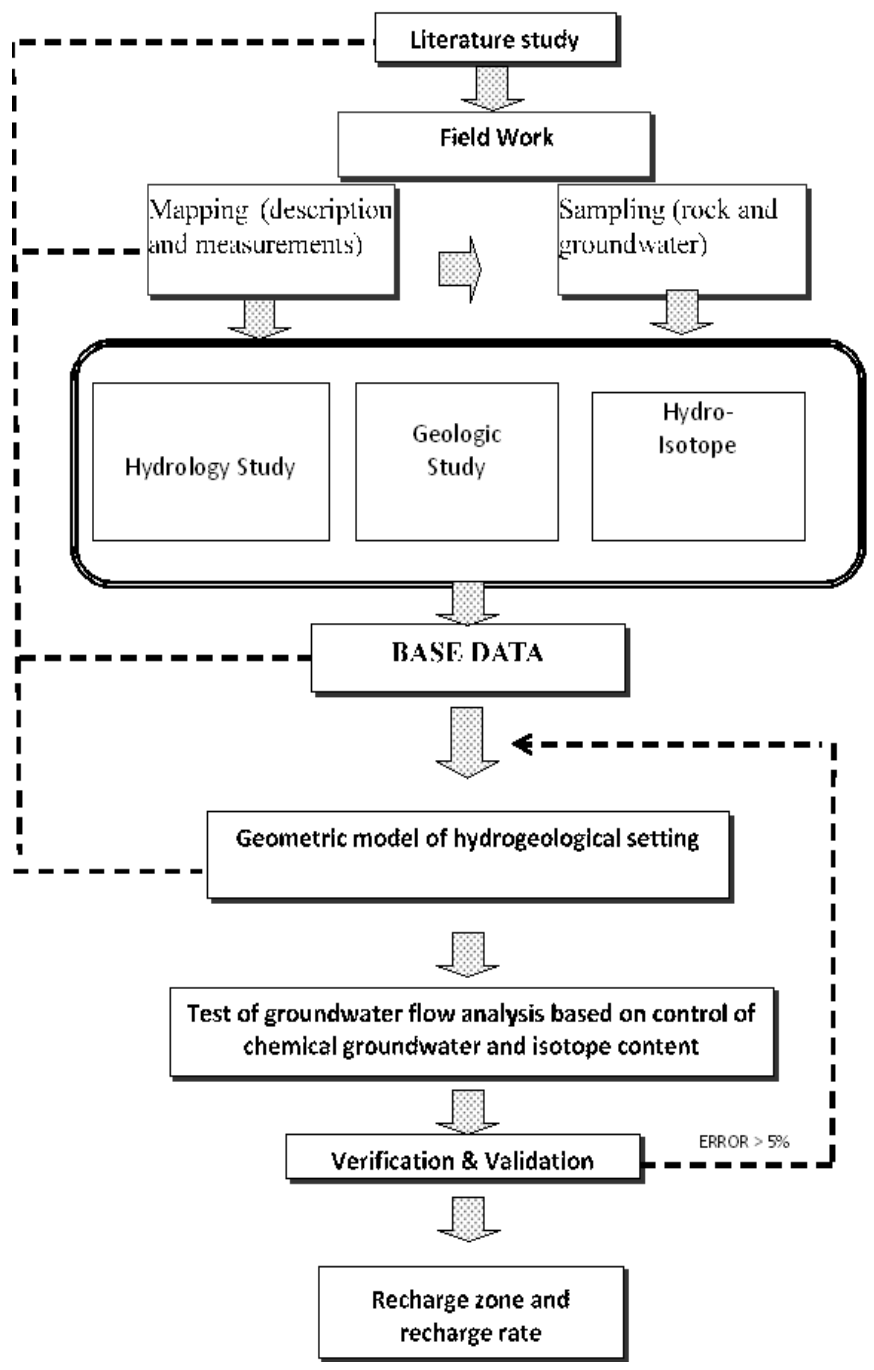

Fig. 1 Diagram for the Research Process

In order to find out the relationship between groundwater samples and aquifer system, the composition diagram method is utilized. In the composition diagram, the measured pair of parameters is plotted in the $x-y$ chart. This diagram presents a quick way to see the relationship between groundwater samples. In this study, the data is planned in the composition diagram includes a comparison of the $\mathrm{pH}, \mathrm{EC}$, TDS, and composition of the main elements towards elevation. The next step is to analyze the chemical content of groundwater as an initial step to identify groundwater facies in the aquifer system.

The facies of groundwater identify groundwater base on the genes and differences of water within systems and bodies where groundwater is found, according to Back, Morgan, and Winner, Seaber [10]. Deuterium and isotopes ${ }^{18} \mathrm{O}$ analysis were calculated by comparing the international standard SMOW (Standard Mean Ocean Water), [11]. This standard is used as an isotope reference ratio of ${ }^{18} \mathrm{O} /{ }^{16} \mathrm{O}$ and $\mathrm{D} / \mathrm{H}\left({ }^{2} \mathrm{H} /{ }^{1} \mathrm{H}\right)$, which has a value of 0 (zero). The isotopic ratio of ${ }^{18} \mathrm{O} /{ }^{16} \mathrm{O}$ and $\mathrm{D} / \mathrm{H}$ of sample related to the standard are expressed by delta notation $(\delta)$ in per mill (\%o), as the following equation:

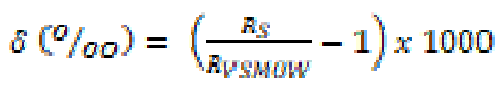

Where, $\mathrm{R}_{\mathrm{S}}$ : isotopic ratio $\mathrm{D} / \mathrm{H}$ or ${ }^{18} \mathrm{O} /{ }^{16} \mathrm{O}$ in the water sample

$\mathrm{R}_{\mathrm{VSMOW}}$ : isotopic ratio of $\mathrm{D} / \mathrm{H}$ or ${ }^{18} \mathrm{O} /{ }^{16} \mathrm{O}$ in standard solution

$\delta$ : $\mathrm{D} / \mathrm{H}$ or ${ }^{18} \mathrm{O} /{ }^{16} \mathrm{O}$ isotopic value of sample relative to standard (\%o). Analysis of $\delta \mathrm{D}$ and $\delta^{18} \mathrm{O}$ in water samples was carried out by using the equipment of Liquid-Water Stable Isotope Analyzer LGR DLT-100 assembled by Los Gatos Research - the USA in Figure 2.

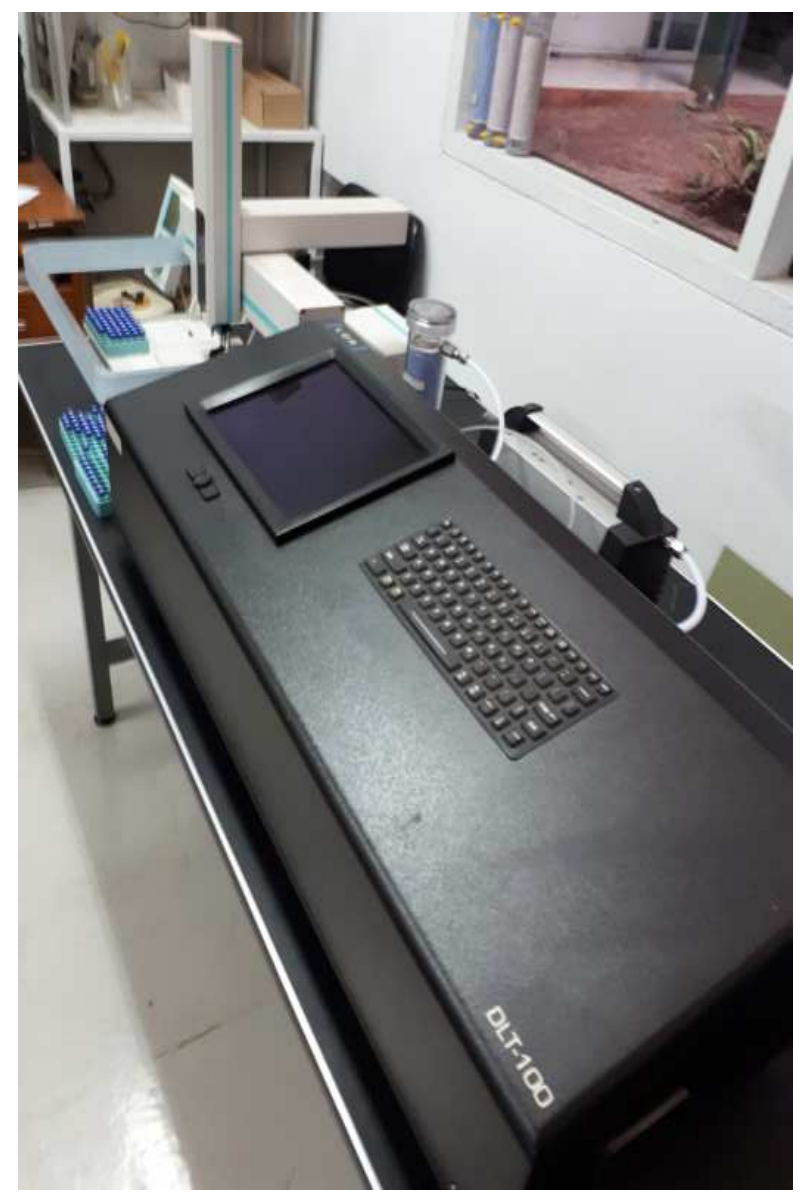

Fig. 2 LGR DLT-100 equipment 
While analysis ${ }^{14} \mathrm{C}$ where carbonate samples in the form of $\mathrm{BaCO}_{3}$ or $\mathrm{CaCO}_{3}$ compounds were witnessed with 450 $\mathrm{ml}$ of $10 \% \mathrm{ml} \mathrm{HCl}$ acid solution under vacuum so that $\mathrm{CO}_{2}$ gas would be obtained through the following reaction equation:

$$
\mathrm{BaCO}_{3}+2 \mathrm{HCl} \rightarrow \mathrm{BaCl}_{2}+\mathrm{H}_{2} \mathrm{O}+\mathrm{CO}_{2}
$$

$\mathrm{CO}_{2}$ gas, which contains ${ }^{14} \mathrm{CO}_{2}$ is then absorbed using around $30 \mathrm{ml}$ Carbosorb-E/Permafluor-E solution on the $\mathrm{CO}_{2}$ absorption line so that it will form a Carbamat solution. A total of $21 \mathrm{ml}$ of Carbamat compound was then poured into a $21 \mathrm{ml}$ glass vial. Then the counting process was carried out using the Liquid Scintillation Analyzer (LSA) 2910TR Perkin Elmer. The counting process was carried out for 20 minutes, with 50 repetitions [12]. The sample radiocarbon age determination calculation is as follows:

$$
t=8267 \ln \left(\frac{A s t d}{A s}\right)
$$

Where, $t$ : the radiocarbon age of the sample

Astd: the net radiocarbon content of the modern standard

As the measured net radiocarbon content of the sample

\section{RESULTS AND DISCUSSION}

\section{A. Results}

The ${ }^{18} \mathrm{O}$ and $\mathrm{D}$ natural isotope data have been analyzed from several springs and boreholes. Based on the data, the results of stable isotope analysis ${ }^{18} \mathrm{O}$ and D in July 2013 still show typical values with values around $-6 \%$ to $-7 \%$ o. But entering August 2013, the stable isotope values of ${ }^{18} \mathrm{O}$ and D tended to be enriched, and their peak in September 2013 was very enriching. This situation is caused by the effects of the dry season so that the isotope value becomes more prosperous than usual.

All stable isotope data ${ }^{18} \mathrm{O}$ and $\mathrm{D}$ are then plotted in graphical form so that the local (meteoric) rain line of the Jatinangor area can be known. The meteoric line graph of the Jatinangor area in Figure 3.

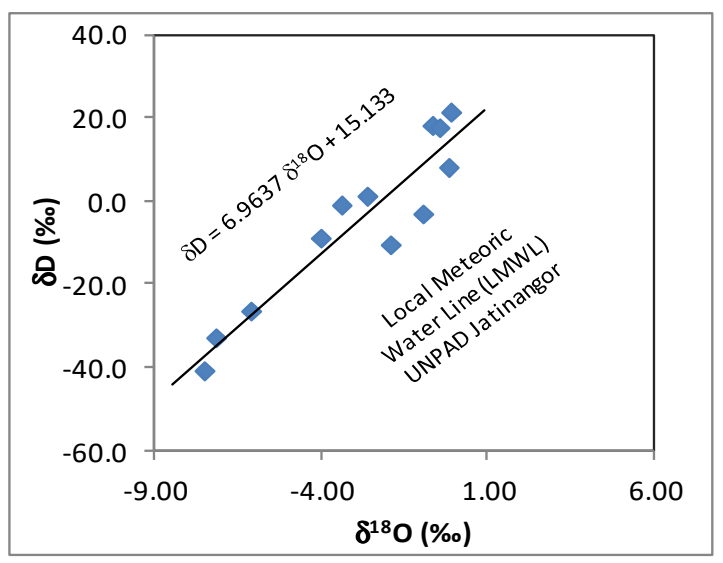

Fig. $3 \delta \mathrm{D}$ vs. $\delta^{18} \mathrm{O}$ relationship graph of rainwater samples in Jatinangor
Data on ${ }^{18} \mathrm{O}$ and $\mathrm{D}$ isotopes derived from samples of bore wells and complete springs can be seen in Table 1.

TABLE I

THE RESULTS OF ${ }^{18} \mathrm{O}$ AND D ISOTOPE ANALYSIS OF SAMPLES FROM

\begin{tabular}{|c|c|c|c|}
\hline No. & Sta Sample & $\delta^{18} \mathrm{O}(\% \text { o })_{\text {smow }}$ & $\delta \mathrm{D}(\% \text { o })_{\text {smow }}$ \\
\hline 1 & ST-06 & -9.17 & -43.9 \\
\hline 2 & ST-002 & -9.71 & -46.1 \\
\hline 3 & ST-008 & -9.53 & -44.5 \\
\hline 4 & ST-009 & -9.22 & -45.7 \\
\hline 5 & ST-005 & -9.53 & -44.8 \\
\hline 6 & ST-013 & -9.04 & -50.5 \\
\hline 7 & ST-015 & -8.63 & -48.0 \\
\hline 8 & ST-001 & -7.88 & -46.8 \\
\hline 9 & ST-014 & -7.39 & -49.9 \\
\hline 10 & ST-010 & -5.88 & -47.6 \\
\hline 11 & ST-004 & -5.96 & -46.3 \\
\hline 12 & ST-011 & -6.32 & -43.1 \\
\hline 13 & ST-007 & -6.38 & -47.9 \\
\hline 14 & ST-012 & -6.80 & -48.2 \\
\hline 15 & SH-007 & -5.45 & -37.1 \\
\hline 16 & SH-008 & -5.84 & -38.0 \\
\hline 17 & BW-005 & -5.86 & -41.0 \\
\hline 18 & BW-006 & -5.99 & -40.4 \\
\hline 19 & MA-004 & -7.58 & -47.1 \\
\hline
\end{tabular}
BOREHOLE WATER AND SPRINGS AT JATINANGOR

The data in Table 1 are then plotted into the local rain line graph of the Padjadjaran University Campus at Jatinangor to see the distribution of the composition. Graphs of relationship D and ${ }^{18} \mathrm{O}$ from samples of bore well water and springs can be seen in Figure 4.

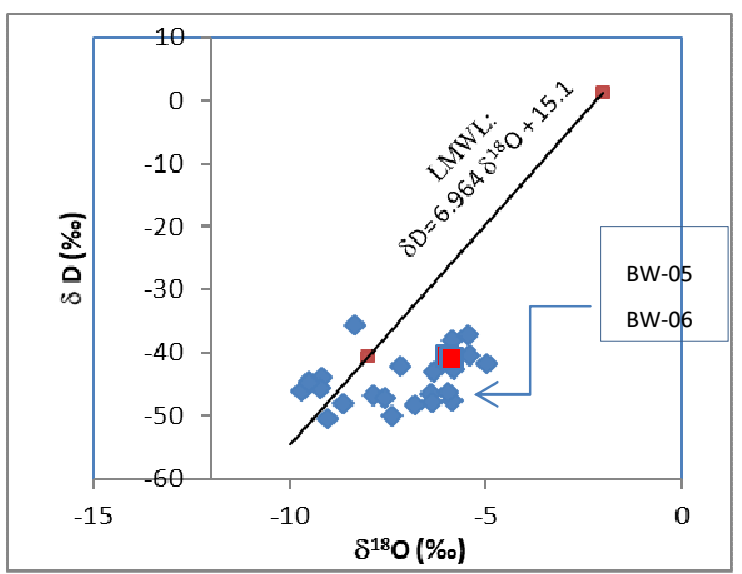

Fig. $4 \delta \mathrm{D}$ vs. ${ }^{18} \mathrm{O}$ Relationship graph of bore well water samples and springs in Jatinangor

It can be seen that the water originating from PDAM bore wells have ${ }^{18} \mathrm{O}$ and $\mathrm{D}$ isotope composition, which is relatively the same as a number of water samples originating 
from springs. While some other examples of springs have different ${ }^{18} \mathrm{O}$ and $\mathrm{D}$ isotope compositions, which indicate having different origins. In order to determine the recharge area origin, a graph of the e value of the stable isotope ratio composition ${ }^{18} \mathrm{O}$ or monthly mean (annual mean) to the height of the rainfall station area is used. Calculation of average monthly rainwater for $\delta^{18} \mathrm{O}$ or $\delta \mathrm{D}$ monthly is done by the following equation:

$$
\delta^{18} O \text { atau } \delta D_{\text {annualmean }}=\frac{\sum I_{n} \times \delta_{n}}{\sum I_{n}}
$$

$\mathrm{I}_{\mathrm{n}}=$ Rainfall intensity $\mathrm{n}$ months in $\mathrm{mm}$

$\delta_{\mathrm{n}}=$ Composition of ${ }^{18} \mathrm{O}$ or Deuterium isotope ratios in month $\mathrm{n}$ in units of $\%$. ' In this study, data for 4 (four) months of rainfall observations were obtained and a graph of the relationship between the composition of monthly ${ }^{18} \mathrm{O}$ and $\mathrm{D}$ isotope ratios to elevation, as shown in figure 5 and figure 6.

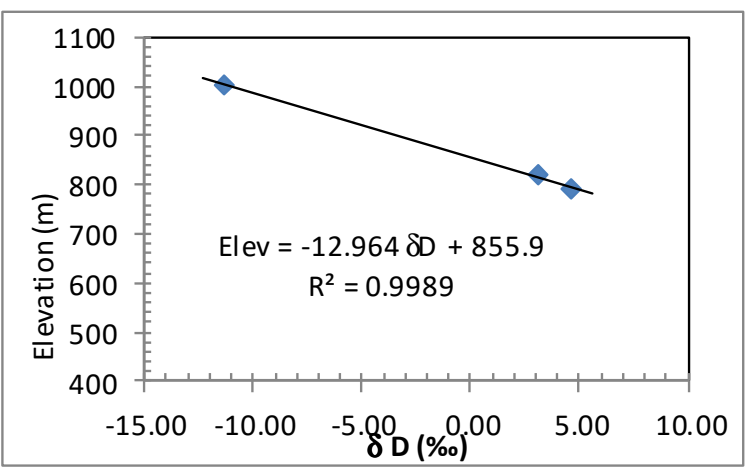

Fig. 5 The relationship of the composition deuterium isotope ratio to the monthly rainwater elevation of Jatinangor

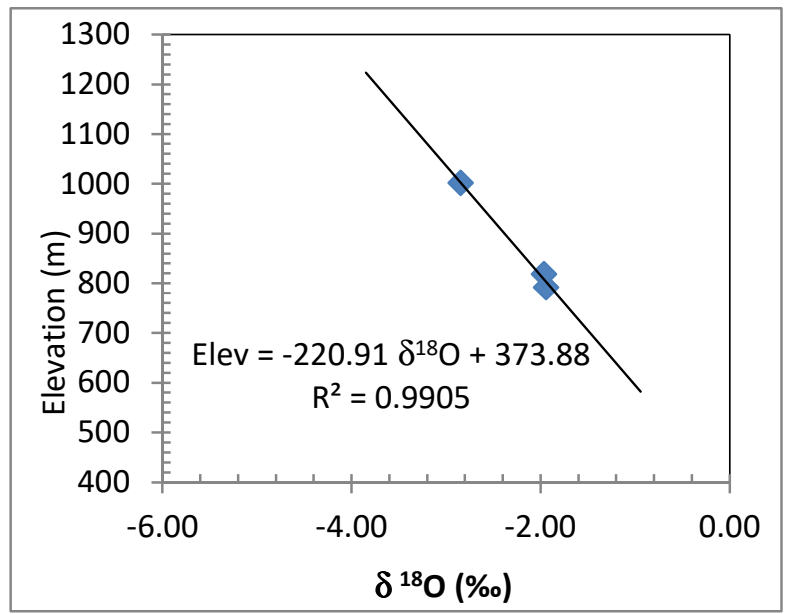

Fig. 6 Relationship of the composition of the 180 isotope ratio to the monthly rainwater elevation of Jatinangor

Based on the equation from the graph, the relationship of the composition of the ratio of $\mathrm{D}$ isotopes and 180 isotopes to the height of each rainfall station as shown in Figures 6 and 7 , the following equation is obtained:

$$
\begin{gathered}
h(m)=-12.964 \times \delta D+855.9 \\
h(m)=-220.91 \times \delta^{18} O+373.88
\end{gathered}
$$

By entering the isotope ratio composition data of the bore wells (BW-005 and BW-006) and springs, the height of each recharge area can be found.

\section{TABLE II}

The CAlculation of Recharge is BASED on The Composition of The ISOTOPE RATIO

\begin{tabular}{|l|l|l|}
\hline \multirow{2}{*}{ Code well } & \multicolumn{2}{|c|}{ Recharge Area } \\
\cline { 2 - 3 } & Based on equation (3) & Based on equation (4) \\
\hline $\begin{array}{l}\text { Borewell PDAM } \\
\text { (BW-005 and }\end{array}$ & $1379-1388$ & $1668-1697$ \\
\hline $\begin{array}{l}\text { BW-006) amount of } \\
\text { spring }\end{array}$ & 1466 & 2048 \\
\hline
\end{tabular}

From the results of calculations in Table 2, it is known that the recharge area for bore wells (BW-005, BW-006) and some springs based on Deuterium data ranged from 1379 $1388 \mathrm{~m}$ and several springs around $1466 \mathrm{~m}$. Meanwhile, based on ${ }^{18} \mathrm{O}$ data, the recharge area is between $1668-1697$ $\mathrm{m}$ for boreholes and some springs, and about $2048 \mathrm{~m}$ for some other springs. However, because of the maximum height of the hill around the Jatinangor UNPAD campus around $1800 \mathrm{~m}$, in general, the catchment area is at an altitude between $1379 \mathrm{~m}$ and $1697 \mathrm{~m}$.

$\underline{\text { Radioisotope }{ }^{14} \mathrm{C}}$

The results of the analysis of ${ }^{14} \mathrm{C}$ groundwater samples from BW-005 and BW-006 drill well samples can be seen in Table 3.

TABLE III

RESULTS OF ANALYSIS OF 14C OF JATINANGOR 2013 GROUNDWATER SAMPLES

\begin{tabular}{|c|c|c|c|}
\hline No. & $\begin{array}{c}\text { Name } \\
\text { Samples }\end{array}$ & $\begin{array}{c}\text { percent Modern Carbon } \\
(\mathrm{pMC})\end{array}$ & Age (years BP*) \\
\hline 1 & BW-005 & $76.82 \pm 0.60$ & $2,120 \pm 30$ \\
2 & BW-006 & $87.32 \pm 0.75$ & $1,090 \pm 20$ \\
\hline
\end{tabular}

$\mathrm{BP}=$ before present $=1950$

Based on ${ }^{14} \mathrm{C}$ analysis data, it can be seen that BW-06 groundwater has a younger age than BW-05. This means the BW-06 has a shorter hydrological cycle compared to BW-05. However, in general, the two groundwater sources are classified as young, so that the continuity of water availability in the Padjadjaran University campus area Jatinangor needs to maintain the water catchment area as determined by analysis of $\mathrm{D}$ and ${ }^{18} \mathrm{O}$ isotopes.

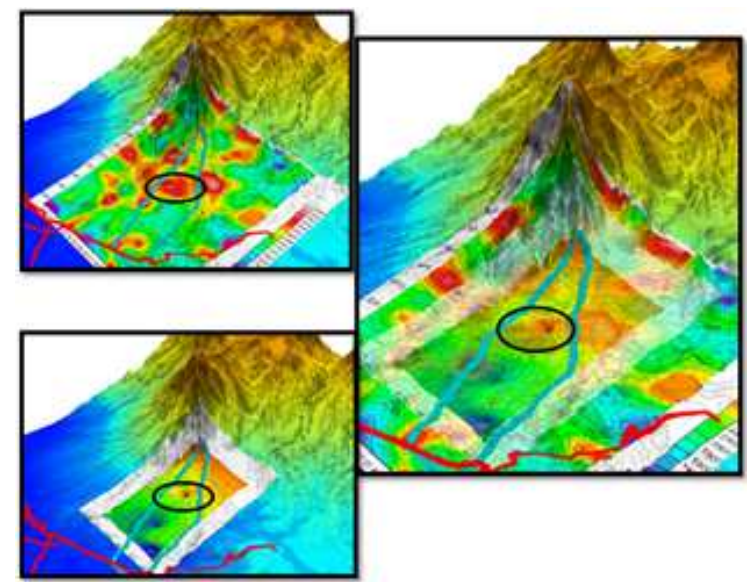

Fig 7 Location of recharge area based on stable water isotopes 


\section{B. Discussion}

This study explains the determination of recharge zones as other researchers have done [13]. In general, the groundwater recharge process occurs through two sequential processes, namely infiltration (movement of water from above to the surface of the ground) and percolation, namely the flow of water from one zone to another zone. Infiltration power is the maximum possible infiltration rate, which is determined by ground conditions. Percolation power is the maximum reasonable percolation rate, the amount of which is determined by the state of the soil in the unsaturated zone. The rate of infiltration is lower due to the high rate of weathering. Therefore there is a need for a development catchment area to increase the infiltration. The research groundwater samples are top in quality with the groundwater facies containing $\mathrm{Ca}, \mathrm{Na}+\mathrm{K}, \mathrm{HCO} 3$, facies $\mathrm{Ca}, \mathrm{Mg} \mathrm{HCO} 3$, and facies $\mathrm{Mg}$, $\mathrm{Ca} \mathrm{HCO} 3$. Groundwater in the recharge area has the local and medial regime.

\section{IV.CONCLUSIONS}

Based on the results of ${ }^{18} \mathrm{O},{ }^{2} \mathrm{H}$ and ${ }^{14} \mathrm{C}$ isotopes, the findings can be drawn: groundwater originating from a spring has a different origin, where one originated from groundwater from the local water company (PDAM) well water source, and the other came from the same elevation as the PDAM's well. The catchment or recharge area for the UNPAD campus in Jatinangor and its surroundings is estimated to be at an altitude of $1379 \mathrm{~m}$ to $1697 \mathrm{~m}$. The age of groundwater originating from PDAM well is classified as young or has a relatively short hydrological cycle. The study also found that environmental preservation in the catchment area is needed to be appropriately maintained. The study output can be used to raise awareness of local authorities that oversee the regulation on groundwater. The government and community need to conduct robotization in the recharge area.

\section{REFERENCES}

[1] Sunarwan, B., Irawan D.E Puradimaja and Nojosiswoyo, S (2-13) Perubahan Karakter Isotope $2 \mathrm{H}$ dan $18 \mathrm{O}$ air Tanah pada akifer Dangkal di Cat Bandung-Soreang. In Prosiding Seminar Nasional Sains dan Teknologi Nuklis PT NBR-Batan Bandung

[2] Geyh MA., "Isotropic Study in the Bandung basin Indonesia", Project Report no 10. DGTL, Ferman Enviromental Geology Advisory Team for Indonesia, Bandung. 1990.,

[3] Hendarmawan, H., \& Satrio, R.Recharge Area on the Slopes of Volcano Based on Geological Setting, Content of Deuteurium, and Oxygen Isotopes of Groundwater Chemistry. Case study on the Slopes of Salak Mountain, West Java. Journal of Tropical Soils, 16(3). (2019)

[4] Adar, E. M., Neuman, S.P., \& Woolhiser, D.A. Estimation of spatial recharge distribution using environmental isotopes and hydrochemical data, I. Mathematical model and application to syntethic data. Journal of hydrology, 97(3-4), 251-277. 1988

[5] Dixon, W., \& Chiswell, B.,"The use of hydrochemical sections to identify recharge areas and saline intrusions in alluvial aquifers Southest Queensland, Australia”. Journal of Hydrology, pp. 135(1-4), 259-274, 1992

[6] Panno, S. V., Hackel, K. C., Catwright, K., \& Liu, C. L. "Hydrochemistry of the Mahomet Bedrock valley Aquifer, east central Illinois Indicators of recharge and ground-water flow". Goundwater, 32(4), 591-604,1994.

[7] Darling, W. G., \& Bath, A. H., 'A stable isotope study of recharge processes in the English Chalk". Journal of Hydrology, pp. 101(1-4), 31-46, 1988.

[8] Matiatos, I., \& Wassenaar, L.L., "Satble isotope patterns reveal widespread rainy-perod-biased recharge in phreatic aquifers across Greece”. Journal of Hydrology, 568, pp 1081-1092, 2019.

[9] Wright, S. N., \& Novakowski, K. S., "Groundwater Recharge, Flow and Stable Isotope Attenuation in Sedimentary and Crystalline Fractures Rock:Spatiotemporal Monitoring from Multi-Level Wells". Journal of Hydrology, 571, pp.178-192, 2019

[10] Freeze, R. A., and Cherry, J. A, "Groundwater", Prentice-Hall Inc Eaglewood Cliffs, NJ. 1979.

[11] Aggarwal, Pradeep K., Klaus FO Froehlich, and Joel R. Gat. Isotopes in the water cycle. Dordrecht: Springer, 2005.

[12] Qureshi, R. M., et al. "A simple prepatory procedure for $\mathrm{LSC}{ }^{14} \mathrm{C}$ dating of environmental samples with ages younger than 29.000 years. 'Proc. Natl. Symp. Spectroscopy for Material Analysis. Islamabad-Pakistan : April. 1995.

[13] Zhu, Juyan, Wang, Y., Guo, H., Zang, X., \& Qin T “Application of Groundwater Model Groundwater Regulation in Cangzhou Area. "E3S Web of Conferences. Vol. 79. EDP Sciences, 2019. 